\title{
Strategies to prevent intraoperative lung injury during cardiopulmonary bypass
}

\author{
Efstratios E Apostolakis ${ }^{1}$, Efstratios N Koletsis ${ }^{1}$, Nikolaos G Baikoussis ${ }^{1,2^{*}}$, Stavros N Siminelakis ${ }^{2}$, \\ Georgios S Papadopoulos ${ }^{3}$
}

\begin{abstract}
During open heart surgery the influence of a series of factors such as cardiopulmonary bypass (CPB), hypothermia, operation and anaesthesia, as well as medication and transfusion can cause a diffuse trauma in the lungs. This injury leads mostly to a postoperative interstitial pulmonary oedema and abnormal gas exchange. Substantial improvements in all of the above mentioned factors may lead to a better lung function postoperatively. By avoiding $C P B$, reducing its time, or by minimizing the extracorporeal surface area with the use of miniaturized circuits of $C P B$, beneficial effects on lung function are reported. In addition, replacement of circuit surface with biocompatible surfaces like heparin-coated, and material-independent sources of blood activation, a better postoperative lung function is observed. Meticulous myocardial protection by using hypothermia and cardioplegia methods during ischemia and reperfusion remain one of the cornerstones of postoperative lung function. The partial restoration of pulmonary artery perfusion during CPB possibly contributes to prevent pulmonary ischemia and lung dysfunction. Using medication such as corticosteroids and aprotinin, which protect the lungs during CPB, and leukocyte depletion filters for operations expected to exceed 90 minutes in CPB-time appear to be protective against the toxic impact of CPB in the lungs. The newer methods of ultrafiltration used to scavenge pro-inflammatory factors seem to be protective for the lung function. In a similar way, reducing the use of cardiotomy suction device, as well as the contact-time between free blood and pericardium, it is expected that the postoperative lung function will be improved.
\end{abstract}

\section{Introduction}

Despite the improvement in the cardiopulmonary bypass $(\mathrm{CPB})$ techniques as well as the postoperative intensive care, impaired pulmonary function is a welldocumented (by enormous experimental and clinical evidence) complication of cardiopulmonary bypass, resulting in increased morbidity and mortality [1-3]. However, whether $\mathrm{CPB}$ itself is directly responsible for the whole postoperative lung dysfunction is still controversial. It is indirectly suggested by some studies following off-pump coronary artery bypass, which although an attenuated inflammatory response has been shown, the degree of postoperative lung dysfunction was similar with that of conventional Coronary Artery Bypass Grafting CABG $[4,5]$. Namely, for this postoperative pulmonary dysfunction $\mathrm{CPB}$ may not be the only factor

\footnotetext{
* Correspondence: ngbaik@yahoo.com
'Department of Cardiothoracic Surgery, University of Patras, School of

* Correspondence: ngbaik@yahoo.com
'Department of Cardiothoracic Surgery, University of Patras, School of Medicine, Patras, Greece
}

contributing, but other factors related to the cardiac operation such as anaesthesia, temporary cardiac dysfunction, infused catecholamines, altered mechanical of thoracic cage, etc could play an important role [3,6-11]. The reported increased mortality and morbidity of this early postoperative pulmonary dysfunction after cardiac surgery may be related to the duration of mechanical ventilation, neurological, renal and infectious complications, ICU and hospital stays, and subsequently increased mortality [12]. Despite the well-documented impairment of pulmonary function even after uncomplicated $\mathrm{CPB}$, effective precautions and ideal management strategies for this problem are still under debate [3,4]. The scope of this review is, therefore, to highlight the path of genetic and pathophysiological mechanisms involved in this injury, and the possible perioperative therapeutic options and manipulations that could be implemented, in order to alleviate the expected postoperative lung dysfunction. 


\section{Methodology and strategy for management of lung dysfunction after cardiac surgery}

\section{Prevention and management of the inflammatory} reaction due to $\mathrm{CPB}$

Since the inflammatory response of CPB is multifactorial, a combined therapeutic approach should be implemented for the attenuation of the clinical sequelae. On the one hand, the abrogation of CPB by using Off-Pump techniques alone is not possible in many cases, and on the other hand, this technique alone does not seem to fully alleviate postoperative lung dysfunction $[13,14]$. Other modifications of $C P B$ techniques, such as the utilization of heparin-coated circuits, use of ultra-filtration techniques or the use of the Drew-Anderson technique, may be beneficial for a reduction in the observed activation of systemic inflammatory response syndrome (SIRS) or the scavenging of various pro-inflammatory cytokines $[4,15,16]$.

\subsection{Inversion to Off-Pump operations}

Although CPB causes disturbances in lung mechanics, it may not be on its own a major contributor to the observed postoperative gas exchange abnormalities following heart operations $[3,17,18]$. To date the experimental and clinical data comparing On-pump and Offpump surgery suggest an affected cardiac function in favour of Off-Pump operations, expressed by a reduced tissue oxygenation, a phenomenon which might be related to a greater myocardial damage during hypothermic CPB operations [14,19-21]. In addition, the higher lactate levels in the $\mathrm{CPB}$ group suggest greater tissue $\mathrm{O}_{2}$ demands after hypothermic CPB perfusion in comparison with those demands with Off-pump surgery [22]. Although initial studies showed reduction in indexes of systemic inflammation after OPCAB and pulmonary complications [23], the negative influence of $\mathrm{CPB}$ on the lungs, is not apparent by comparing conventional CABG with Off-Pump Coronary Artery Bypass (OPCAB). Indeed, some clinical studies showed that, both Onpump and Off-pump CABG patients experienced similar degrees of decreased $\mathrm{PaO}_{2}$ and increased $\mathrm{P}(\mathrm{A}-\mathrm{a}) \mathrm{O}_{2}$, but a higher percentage of pulmonary shunt fraction after On-pump operations $[17,18,24]$. However, a randomized study by Staton et al [25] compared the postoperative lung function after OPCAB and conventional CABG, concerning fluid balance, hemodynamics, arterial blood gases, chest radiographs, spirometry, pulmonary complications, and extubation-time. Paradoxically, postoperative compliance was reduced more after OPCAB, and fluid balance was significantly higher in the same group. Despite these changes, immediate postoperative $\mathrm{PaO}_{2}$ on $\mathrm{FiO}_{2}$ of 1.0 was significantly higher after OPCAB and extubation-time was significantly shorter, while the postop-chest radiographs, spirometry, mortality, re-intubation, or re-admission for pulmonary complications, were not significantly different between groups [25]. In conclusion, although it is impossible to perform all the heart operations without $\mathrm{CPB}$, this hypothetical inversion alone cannot prevent systemic inflammatory reaction and lung function impairment. Although this scenario can abolish the negative effects of $\mathrm{CPB}$ on lung function it is not able to diminish completely the proinflammatory factors that are produced, despite the fact that the postoperative lung impairment seems to be generated to a lesser extent.

\subsection{Heparin-coated circuits and new-technology circuits}

The hostile surface of extracorporeal circuit is considered to be a major factor of inflammatory reaction. Over the last years a large improvement has been observed in the construction and the clinical use of circuits lined with more biocompatible coating. The following have been used as coating materials: heparin $[4,15,16]$, poly-2-methoxyethyl acrylate [26], synthetic protein [27], and phosphorylcholine [28]. The first and most extensively studied coating material used is that of heparin. The concept behind heparin coating is to mimic the endothelial surface that contains heparin sulphate [2]. Hence, the main beneficial effects of heparincoated circuits are considered to be the following two: first, a reduction of complement activation (and mainly of factor C5a) ranging between $25 \%$ and $45 \%[29,30]$, and second, a reduction of the inflammatory reaction which is thought to be accomplished in two ways: through a reduction of complement activation, and through binding of phospholipase $\mathrm{A}_{2}$ [31]. Heparin reduces the inflammatory responses especially as far as the actions of platelets, leukocytes, and endothelial cells are concerned [31-34]. This effect is noticeable by a decreased production of IL-6, IL-8, E-selectin, lactoferin, myeloperoxidase, integrin, selectin, and platelet $\beta$ thromboglobulin release, and reduced production of oxygen free radicals, as well [31-34]. Concisely, all the above described effects of heparin-coated circuits should have beneficial impact on clinical outcomes. Indeed, a clinical study showed a decreased intrapulmonary shunt with improved respiratory index $\left(\mathrm{PO}_{2} / \mathrm{FiO}_{2}\right)$ after $\mathrm{CPB}$ by using heparin-coated circuits, although intubation time and ICU stay were not affected [35]. Others, using a scoring-system based either on intubation time, the central-peripheral temperature difference, the postoperative fluid balance, and on various adverse effects after CABG, showed a significantly positive clinical effect in patients treated with heparin-coated circuits, and especially in patients with cross-clamp times exceeding 60 min [16,36]. De Vroege et al [31] demonstrated comparatively significant postoperative differences in favour of the patients treated with heparin-coated circuits in terms of the pulmonary shunt fraction, the pulmonary 
vascular resistance index, and the $\mathrm{PaO}_{2} / \mathrm{FiO}_{2}$ ratio, as well as various inflammatory markers reflecting complementary activation. In addition, they found reduced activation of pulmonary capillary endothelial cells in the same group of patients, suggesting that the heparincoated circuit may have beneficial effects on pulmonary function [31]. Compared with conventional circuits, the heparin-coated may improve lung compliance and pulmonary vascular resistance and thus reduce intrapulmonary-shunt [37]. However, most clinical studies have shown, that these beneficial effects did not influence the intubation-time or the ICU-stay of patients $[31,37,38]$. Furthermore, in contrast to initial expectations, thrombin generation and the activity of the fibrinolytic system were not reduced using heparin-coated circuits [39]. Recently, Speekenbrink et al [40], proposed a novel miniaturized CPB system with the aim to attenuate lung and other organ dysfunction, and generally to diminish the inflammatory reaction and the derangement of patient homeostasis. The principles of this system described also by others [40-43] are the following: it uses a low prime volume of only 800 versus $2000 \mathrm{ml}$ for the conventional system; all of circuit components are heparincoated and primed with aprotinin; it is a closed-volume system; it uses an additional pump for the venous line; and in addition, it uses a "controlled-suction' system, or a "cell-saving" system, to minimize the contact-time between blood and non-endothelialized tissues. A large amount of the priming volume can be extracted from the extracorporeal circuit by "controlled exsanguinations" of the patient into the circuit, and as a result the unpleasant hemodilution may be reduced [40]. By using his system, the reduction in complementary activation is reduced by 25 to $45 \%$ and as a result, the expected impairment on lung function is reduced [40]. Nollert at al [44] compared the outcomes with conventional CPB and miniaturized cardiopulmonary bypass after CABG in 30 patients, concerning the inflammation and coagulation, measuring levels of IL-2, IL-6, IL-10, TNF, CRP, WBC differentiation, d-dimers, fibrinogen, and platelet's number. Surprisingly, they did not find any significant difference of any parameter of inflammation or clinical outcomes (blood loss, need for blood products, ICU-stay and hospital-stay) amongst the two groups. However, in two cases dangerous air leaks occurred in the closed miniaturized circuit, suggestive of a more narrow safety margin. Therefore, the expected protective effect on lung function by using these systems seems to be insufficient for broad clinical use at the time this review is written.

\subsection{Leukocyte depletion}

Since experimental studies have documented that leukocytes were entrapped into the capillaries of lungs [45] and play an important role in the inflammatory reaction after $\mathrm{CPB}$, their depletion during $\mathrm{CPB}$, may be beneficial. Indeed, experimental studies showed that leukocyte depletion by filtration reduced heart and lung reperfusion injury [45]. However, clinical comparative studies have shown ambiguous results. Some of them showed better preserved lung function and reduced free oxygen radicals production following $\mathrm{CPB}$, expressed by improved $\mathrm{PaO}_{2}$ [45-47] while others did not show any difference $[48,49]$ despite the reduced IL-8 production [48]. Other studies have shown, that, although the leukocyte depletion filter of the arterial line removes leukocytes from the circulation, the systemic neutrophil count may $[49,50]$ or may not be reduced [51]. A randomized study compared the effectiveness of leukocyte filter depletion with a common arterial filter, in patients undergoing conventional CABG. They found significantly better oxygenation indices; lower extravascular lung water scores, and less duration of postoperative mechanical ventilation in the leukocyte depletion filter group [52]. In addition, leukocyte filtration did not offer any significant preservation of lung function, for CPBtime less than 90 minutes. Warren et al [53], in their extensive review examined the effectiveness of several leukocyte depletion filters, used in cardiac surgery. They concluded that: a) whilst the filters did not appear to significantly lower leukocyte count, they may preferentially remove activated leukocytes, b) a small improvement in lung function is evident early postoperatively, but this does not lead to decrease mortality or better clinical outcomes, c) their use attenuates the reperfusion injury at the cellular level, but without substantial clinical improvement, and d) up to date there are no evidence-based data to support the routine use in cardiac surgery.

\subsection{Ultrafiltration}

Ultrafiltration was used in cardiac surgery for removing volume of priming and reducing the postoperative oedema, the total body water, but specifically that of lungs resulting in better oxygenation postoperatively $[54,55]$. Besides this function, it has been postulated that ultrafiltration may remove also destructive and inflammatory substances from the circulation, inflammatory cytokines, and scavenge toxins [56]. Indeed, various studies have shown that by using ultrafiltration the levels of IL-6, IL-8, as well as systemic oedema formation, or pulmonary hypertension can be effectively reduced, while concomitant improvement of the lung function (reduced alveolar-capillary oxygen pressure gradient) is recorded [56-58]. Another comparative study in children showed, that the conventional ultrafiltration resulted in a significant immediate improvement in static lung compliance and dynamic lung compliance, as well as gas exchange capacity. However, this effect is observed only for the first 6 postoperative hours and did not result in 
significant improvement of clinical outcomes (intubation-time, ICU-stay, or hospital-stay) [57]. A similar comparative study ${ }^{54}$ showed that: a) the pulmonary function was improved via a significantly increased pulmonary compliance, a decreased airway resistance and an improved pulmonary gas exchange after $\mathrm{CPB}$, as reflected by a decreased alveolo-arterial oxygen gradient, b) the levels of serum IL-6 in the modified ultrafiltration group were much lower than in the control group, c) the thromboxane B2 was significantly removed by ultrafiltration contributing to a lower lung vessels permeability, and, finally, d) ultrafiltration did not affect the levels and the action of endothelin-1. Finally, the main advantage of ultrafiltration seems to be, in our opinion, the desirable increase of colloid oncotic pressure which subsequently prevents the development of pulmonary interstitial oedema.

\subsection{Hemodilution}

The mixing of the priming solution with the patient's own blood at the beginning of CPB results in an abrupt hemodilution [48]. This hemodilution is desirable, since it facilitates the tissue-perfusion. However, if the hematocrit is restored below a level of $23 \%$, it has been shown to contribute to an increased interstitial oedema in vital organs (e.g., brain, lungs, myocardium), resulting in increased mortality [59]. Consequently, by increasing the colloid oncotic pressure of the priming solution (replacement of crystalloids with colloids), Jansen et al showed that the postoperative course was improved and the hospital-stay significantly reduced [60]. Another study showed that better hemodynamic parameters such as arterial pressure, cardiac index, and vascular resistance, and higher oxygen delivery can be achieved by the reduction of priming volumes [61].

Similarly, other methods used to prevent excessive hemodilution during extracorporeal circulation, such as the use of blood cardioplegia or perioperative hemofiltration, showed even further reduction of blood transfusions [40].

In conclusion, clinical data suggests that the most important result of "controlled hemodilution" contribute to a reduced interstitial lung oedema and therefore to an improvement of postoperative lung function.

\subsection{The cardiotomy suction}

Various studies have shown that the collected pericardial blood during the cardiac operations using $\mathrm{CPB}$, is activated by tissue plasminogen activator ( $t$-PA), while it has been additionally found to contains pro-coagulants and platelets factors $[40,62]$. However, this does not mean that this specific blood is partially activated or that it contains fibrinogen degradation products, and, that its re-transfusion may interact with platelets to form undesirable complexes, and derangements of haemostasis [40]. Indeed, various clinical studies have confirmed that the re-transfusion of blood collected in the pericardium during $\mathrm{CPB}$ induces a dose-dependent inflammatory response, impairs hemostasis, enhance various inflammatory reactions, and also impair the postoperative lung function $[63,64]$. In order to reduce this cascade of activation of pericardial blood, various techniques have been proposed. First, a reduction of time between the contact of shed blood with the pericardium and its re-transfusion might diminish the induced inflammatory reaction $[40,65]$. Second, the use of a controlled suction device which incorporates a level sensor that is activated only when blood accumulates in the pericardium, minimizes air entering into the suction line, and thus the formation of activating air-blood interfaces [40]. Third, the topical administration of aprotinin into the surgical wound and the pericardium has been shown to inhibit the hyper-fibrinolysis that occurs in the pericardial blood which in turn leads to improved hemostasis [66]. Finally, since heparin levels in the reaspirated pericardial blood have been shown to be lower than systemic levels, topical administration of heparin might also reduce the activation of pericardial blood, by reducing thrombin activity [67].

\subsection{Pharmacological manipulations}

\section{Corticosteroids}

An experimental study showed that after pre-treatment with methylprednisolone the postoperative lung function, expressed by alveolar-arterial oxygen gradient, pulmonary vascular resistance, and extracellular lung water, was improved [68]. In a similar way, clinical studies have shown that administration of corticosteroids before $\mathrm{CPB}$ inhibits the production of pro-inflammatory cytokines IL-6, IL-8, and TNF $\alpha$, while it simultaneously increases the IL-10 levels, which exerts an anti-inflammatory action $[16,69]$. Other studies showed that methylprednisolone administration can inhibit neutrophil CD11b expression and neutrophil complementinduced chemotaxis, thereby decreasing neutrophil activation and post-CPB neutropenia [4,70-72]. In contrast, other clinical studies did not obtain to confirm the superiority of methyl-prednisolone administration during cardiac surgery concerning the postoperative alveolar-arterial oxygen gradient, the pulmonary shunt, the lung compliance or the intubation-time [73,74]. However, although evidence-based guidelines are still lacking, some authors remain adherents of steroid administration and consider it as a "fundamental strategy" in their fast-track recovery protocol $[4,15,72]$.

Aprotinin

Hill et al in a clinical study described that the administration of aprotinin in patients following $\mathrm{CPB}$ reduced the levels of TNF- $\alpha$, neutrophil elastase release, complementary activation, neutrophil CD11 upregulation, as well as lower IL-8 levels in the bronchoalveolar lavage 
(BAL) fluid and pulmonary neutrophil sequestration $[71,75]$. Others reported that these effects of aprotinin on the inflammatory response to CPB were dose dependent [76]. Specimens from the lung of patients receiving aprotinin before CPB contained reduced levels of of malondialdehyde, a marker of oxygen free radical damage, higher glutathione peroxidase levels, and reduced leukocyte sequestration [77]. The addition of aprotinin in the priming solution in recipients undergoing heart transplantation showed, that the inflammatory response, and in particular the postoperative pulmonary dysfunction, were both attenuated, resulting in a reduced postoperative morbidity and ICU-stay [78]. Heparin

Heparin is nowadays still considered as absolutely necessary for open heart operations. On the other hand, studies have shown that heparin administration a), results in a rapid release of t-PA from its body sources, which may induce fibrinolysis [79], b) causes (in vitro) inhibition of platelet function in more than $30 \%$ of patients, thus leading to increased postoperative blood loss [80], c) has pro-activating properties on granulocytes and platelets [81], and finally d), heparin after its neutralization with protamine, is inducing an activation of the complement system, action which is correlated with postoperative pulmonary shunt fraction [82]. To avoid these adverse effects of heparin, some possible alternatives have been proposed. The recombinant form of plateletfactor 4, which binds and subsequently inhibits heparin, could be used as an attractive alternative to protamine [83]. Recombinant hirudin, a selective thrombin inhibitor derived from leeches, is another possible attractive alternative [40], which has shown in experiments good clinical results without increased bleeding tendency $[40,84]$. However, disadvantages from the use of recombinant hirudin are the absence of specific antidote, the possible activation and depletion of other factors of the coagulation cascade, as well as it does not completely inhibit the formation of thrombin [40]. Therefore, heparin still remains irreplaceable but possibly in the near future there might be a role for hirudin as an adjunct to heparin.

Monoclonal anticytokine antibodies

To date some authors believe, that in the near future the perioperative administration of monoclonal anticytokine antibodies which reduce the levels of pro-inflammatory cytokines during open heart operations, might attenuate the harmful influence of $\mathrm{CPB}$ on the lungs $[5,15,40]$.

\subsection{Continuing ventilation during $C P B$}

Apnoea during $\mathrm{CPB}$ has been suggested to promote activation of lysosomal enzymes in the pulmonary circulation, which in turn are correlated with the incidence of postoperative pulmonary dysfunction (ALI or ARDS)
[85]. To prevent this dysfunction, it has been applied some maneuvers such as the intermittent ventilation or application of continuous airway pressure (CPAP) during $\mathrm{CPB}[5,40,86]$. CPAP application during $\mathrm{CPB}$ has been reported as an effective adjunct in some studies $[86,87]$. However, others reported either no difference, or a non-significant difference lasting less than 4 to 8 hours between patients treated with CPAP compared to controls $[9,88,89]$. Maintaining ventilation together with pulmonary artery perfusion during $\mathrm{CPB}$ has been proposed as another option to attenuate the post-CPB impairment of lung function. Indeed, Friedman et al [90] in an experimental comparative study showed that ventilation with pulmonary artery perfusion during $\mathrm{CPB}$ should have a beneficial role in preserving lung function, possibly by reducing platelet and neutrophil sequestration and attenuating the $\mathrm{TXB}_{2}$ response after CPB. In contrast to this, another experimental study showed that continuous ventilation during CPB provided no significant improvement in pulmonary vascular resistance, respiratory index, or oxygen tensions [91]. More recently, John et al [92] showed in their randomized study that continued ventilation during $\mathrm{CPB}$ by tidal volume of $5 \mathrm{ml} / \mathrm{Kg}$ resulted significant smaller extravascular lung water and a shorter extubation-time. To date, the evidence for clear benefits of maintaining ventilation alone during $\mathrm{CPB}$ is inconsistent, with most studies showing no significant preservation of lung function $[5,88]$. Similarly, no differences in pulmonary membrane permeability were found between ventilated and nonventilated patients undergoing $\mathrm{CPB}$ [93].

\section{Prevention and management of other (except of} cardiopulmonary bypass) causes of lung dysfunction

Indirect factors of lung dysfunction are the ischemia and reperfusion of the heart, which have been linked with increased production some pro-inflammatory factors $[29,94,95]$. Myocardial cooling and cardioplegia perfusion have been shown to attenuate the negative effects of ischemia on the heart after cross-clamping of the aorta, by reducing the metabolic demand of the myocardium [40]. Nevertheless, ischemia will occur or is already present owing to the disease process that is being treated. The ischemia will consume high-energy phosphate of cells and may cause a degree of reversible or irreversible myocardial damage [40]. Proposed mediators of reperfusion injury following ischemia involve the generation of oxygen free radicals produced via the xanthine oxidase reaction. Exposure of the ischemic endothelium to these radicals induces a rapid up-regulation of P-selectin and integrin expression [96]. At the beginning of reperfusion this will result in the accumulation of more activated neutrophils, which shed their cytotoxic enzymes, cytokines, and oxygen free radicals on the endothelium, leading finally to an extensive tissue 
injury [40]. Damage to receptors involved in the activation of nitric oxide (NO) synthase will reduce NO production which may produce coronary spasm and the no-reflow phenomenon $[97,98]$. Possible ways to reduce reperfusion injury include maintenance of physiological oxygen concentration during $\mathrm{CPB}$, oxygen radical scavengers administration, inhibition of xanthine oxidase by allopurinol, as well as drastic reduction of ischemia by using continuous warm blood cardioplegia techniques [99-102].

\section{Conclusions}

It is clear that many factors are involved in the detrimental effects of CPB in all organs and especially in the lungs [3]. Therefore, substantial improvements in the process of $\mathrm{CPB}$ can only be obtained when a multi-factorial approach is followed, directed at both materialdependent and material-independent factors [40]. There is a huge research to this direction and most of the results are still debatable. However, we could herein summarize the most important beneficial manipulations.

a) By abolition of $\mathrm{CPB}$ or by reducing as much as possible its time, a better postoperative lung function is expected [103,104].

b) By minimizing the extracorporeal-circuit surface area (miniaturized-circuits), the endothelial injury, the granulocytes sequestration and its activation is expected to be much lower $[105,106]$.

c) By replacement of circuit-surfaces with "biocompatible" surfaces as these of heparin-coated, and material-independent sources of blood activation, the expected post-CPB lung injury should be lower [31,40].

d) By maintaining pulmonary artery perfusion during $\mathrm{CPB}$, the lung ischemia is prevented $[15,90,107,108]$.

e) By using "lung-protective" medication such as corticosteroids and aprotinin, the lungs should be protected against the toxic influence of $\mathrm{CPB}$ $[4,72,77,102]$.

f) By using selectively the Drew-Anderson technique to abrogate the xenograft oxygenator, the reduced granulocyte sequestration in the lungs and the minimal complement activation preserve a better postoperative lung function $[109,110]$ the font was corrected here

g) By using (conventional or modified) ultrafiltration during $\mathrm{CPB}$, some pro-inflammatory factors especially "toxic" for the lung function are scavenged [54-56].

h) By drastic reduction of cardiotomy suction to the minimum or by using a controlled cardiotomy suction system which minimizes superfluous suctioning and air entering the pericardial suction line, the postoperative lung function is significantly preserved [48,62-65].

i) By using leukocyte depletion filters for expected long-lasting CPB-time ( $>90$ minutes), a reduced free oxygen radicals production and a better preserved lung function can be achieved $[5,52,53]$.

j) By meticulous application of rules of myocardial protection (during ischemia and reperfusion) the lungs are indirectly protected from several proinflammatory factors produced during this process $[96,101]$.

\section{Author details}

'Department of Cardiothoracic Surgery, University of Patras, School of Medicine, Patras, Greece. ${ }^{2}$ Department of Cardiac Surgery, University of Ioannina, School of Medicine, loannina, Greece. ${ }^{3}$ Department of Clinical Anaesthesiology and Intensive Postoperative Care Unit, University of loannina, School of Medicine, loannina, Greece.

\section{Authors' contributions}

All authors: 1. have made substantial contributions to conception and design, or acquisition of data, or analysis and interpretation of data; 2. have been involved in drafting the manuscript or revisiting it critically for important intellectual content; 3 . have given final approval of the version to be published.

\section{Competing interests}

The authors declare that they have no competing interests.

Received: 24 September 2009

Accepted: 11 January 2010 Published: 11 January 2010

\section{References}

1. Menasche P, Edmunds LHJ: The inflammatory response, Cardiac Surgery in the Adult. McGraw HillCohn LH, Edmunds LH , 2 2003, 349-60.

2. Altmay E, Karaca P, Yurtseven N, Ozkul V, Aksoy T, Ozler A, Canik S: Continuous positive airway pressure does not improve lung function after cardiac surgery. Can J Anaesth 2006, 53:919-25.

3. Apostolakis E, Filos K, Koletsis E, Dougenis D: Lung Dysfunction Following Cardiopulmonary Bypass. J Card Surg 2009

4. Hall RI, Smith MS, Rocker G: The systemic inflammatory response to cardiopulmonary bypass: pathophysiological, therapeutic, and pharmacological considerations. Anesth Analg 1997, 85:766-82.

5. $\mathrm{Ng}$ CS, Wan S, Yim AP, Arifi AA: Pulmonary dysfunction after cardiac surgery. Chest 2002, 121:1269-77.

6. Taggart DP, el Fiky M, Carter R, Bowman A, Wheatley DJ: Respiratory dysfunction after uncomplicated cardiopulmonary bypass. Ann Thorac Surg 1993, 56:1123-8.

7. Vargas FS, Cukier A, Terra-Filho M, Hueb W, Teixeira LR, Light RW Relationship between pleural changes after myocardial revascularization and pulmonary mechanics. Chest 1992, 102:1333-6.

8. Hill GE, Whitten CW, Landers DF: The influence of cardiopulmonary bypass on cytokines and cell-cell communication. J Cardiothorac Vasc Anesth 1997, 11:367-75.

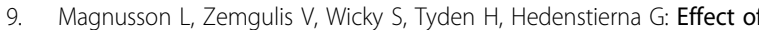
CPAP during cardiopulmonary bypass on postoperative lung function. An experimental study Acta Anaesthesiol Scand 1998, 42:1133-8.

10. Boldt J, King D, Scheld HH, Hempelmann G: Lung management during cardiopulmonary bypass: influence on extravascular lung water. $J$ Cardiothorac Anesth 1990, 4:73-9.

11. Chai PJ, Williamson JA, Lodge AJ, Daggett CW, Scarborough JE, Meliones JN, Cheifetz IM, Jaggers JJ, Ungerleider RM: Effects of ischemia on pulmonary dysfunction after cardiopulmonary bypass. Ann Thorac Surg 1999, 67:731-5. 
12. Rady MY, Ryan T, Starr NJ: Early onset of acute pulmonary dysfunction after cardiovascular surgery: risk factors and clinical outcome. Crit Care Med 1997, 25:1831-9.

13. Tschernko EM, Bambazek A, Wisser W, Partik B, Jantsch U, Kubin K, Ehrlich M, Klimscha W, Grimm M, Keznickl FP: Intrapulmonary shunt after cardiopulmonary bypass: the use of vital capacity maneuvers versus offpump coronary artery bypass grafting. I Thorac Cardiovasc Surg 2002, 124:732-8.

14. Puskas JD, Williams WH, Duke PG, Staples JR, Glas KE, Marshall JJ, Leimbach M, Huber P, Garas S, Sammons BH, McCall SA, Petersen RJ, Bailey DE, Chu H, Mahoney EM, Weintraub WS, Guyton RA: Off-pump coronary artery bypass grafting provides complete revascularization with reduced myocardial injury, transfusion requirements, and length of stay: a prospective randomized comparison of two hundred unselected patients undergoing off-pump versus conventional coronary artery bypass grafting. J Thorac Cardiovasc Surg 2003, 125:797-808.

15. Richter JA, Meisner H, Tassani P, Barankay A, Dietrich W, Braun SL: DrewAnderson technique attenuates systemic inflammatory response syndrome and improves respiratory function after coronary artery bypass grafting. Ann Thorac Surg 2000, 69:77-83.

16. Jansen PG, te VH, Huybregts RA, Paulus R, Bulder ER, Spoel van der HI Bezemer PD, Slaats EH, Eijsman L, Wildevuur CR: Reduced complement activation and improved postoperative performance after cardiopulmonary bypass with heparin-coated circuits. I Thorac Cardiovasc Surg 1995, 110:829-34.

17. Cox CM, Ascione R, Cohen AM: Effect of cardiopulmonary bypass on pulmonary gas exchange: a prospective randomised study. Ann Thorac Surg 2000, 69:140-5.

18. Kochamba GS, Yun KL, Pfeffer TA, Sintek CF, Khonsari S: Pulmonary abnormalities after coronary arterial bypass grafting operation: cardiopulmonary bypass versus mechanical stabilization. Ann Thorac Surg 2000, 69:1466-70.

19. Van Dijk D, Nierich AP, Jansen EWL, Nathoe HM, Suyker WJL, Diephuis JC, Van Boven WJ, Borst C, Buskens E, Grobbee DE, Robles de Medina EO, De Jaegere PPT: Early outcome after off-pump versus on-pump coronary bypass surgery: results from a randomized study. Circulation 2001, 104:1761-6.

20. Khan NE, De Souza A, Mister R, Flather M, Claque J, Davies S, Collins P, Wang D, Sigwart U, Pepper J: A randomized comparison of off-pump and on-pump multivessel coronary artery bypass surgery. N Engl I Med 2004, 350:21-8.

21. Kobayashi J, Tashiro T, Ochi M, Yaku H, Watanabe G, Satoh T, Tagusari O, Nakajima H, Kitamura S: Early outcome of a randomized comparison of off-pump and on-pump multiple arterial coronary revascularization. Circulation 2005, 112:1338-1343.

22. Groeneveld AJ, Jansen EK, Verheij J: Mechanisms of pulmonary dysfunction after on-pump and off-pump cardiac surgery: a prospective cohort study. J Cardiothorac Surg 2007, 2(11):11.

23. Yokoyama T, Baumgartner FJ, Gheissari A, Capouya ER, Panagiotides GP, Declusin RJ: Off-pump versus on-pump coronary bypass in high-risk subgroups. Ann Thorac Surg 2000, 70:1546-50.

24. Taggart DP: Respiratory dysfunction after cardiac surgery: effects of avoiding cardiopulmonary bypass and the use of bilateral internal mammary arteries. Eur J Cardiothorac Surg 2000, 18:31-7.

25. Staton GW, Williams WH, Mahoney EM, Hu J, Chu H, Duke PG, Puskas JD: Pulmonary outcomes of off-pump vs on-pump coronary artery bypass surgery in a randomized trial. Chest 2005, 127:892-901.

26. Suhara H, Sawa $Y$, Nishimura M, Oshiyama H, Yokoyama K, Saito N, Matsuda $\mathrm{H}$ : Efficacy of a new coating material, PMEA, for cardiopulmonary bypass circuits in a porcine model. Ann Thorac Surg 2001, 71:1603-8.

27. Wimmer-Greinecker $G$, Matheis $G$, Martens $S$, Oremek $G$, Abdel-Rahman $U$, Moritz A: Synthetic protein treated versus heparin coated cardiopulmonary bypass surfaces: similar clinical results and minor biochemical differences. Eur J Cardiothorac Surg 1999, 16:211-7.

28. De Somer F, Francois K, van Oeveren W, Poelaert J, De Wolf D, Ebels T, Van Nooten G: Phosphorylcholine coating of extracorporeal circuits provides natural protection against blood activation by the material surface. Eur $J$ Cardiothorac Surg 2000, 18:602-6.
29. Videm V, Svennevig JL, Fosse E, Semb G, Osterud A, Mollnes TE: Reduced complement activation with heparin-coated oxygenator and tubings in coronary bypass operations. J Thorac Cardiovasc Surg 1992, 103:806-13.

30. Ovrum E, Mollnes TE, Fosse E, Holen EA, Tangen G, Abdelnoor M, Ringdal MA, Oystese R, Venge P: Complement and granulocyte activation in two different types of heparinized extracorporeal circuits. J Thorac Cardiovasc Surg 1995, 110:1623-32.

31. de Vroege R, van Oeveren W, van Klarenbosch J, Stooker W, Huybregts MA, Hack CE, van Barneveld L, Eijsman L, Wildevuur CR: The impact of heparincoated cardiopulmonary bypass circuits on pulmonary function and the release of inflammatory mediators. Anesth Analg 2004, 98:1586-94.

32. Weerwind PW, Maessen JG, van Tits $\sqcup$, Stad RK, Fransen EJ, de Jong DS, Penn OC: Influence of Duraflo II heparin-treated extracorporeal circuits on the systemic inflammatory response in patients having coronary bypass. I Thorac Cardiovasc Surg 1995, 110:1633-41.

33. Bozdayi M, Borowiec J, Nilsson L, Venge P, Thelin S, Hansson HE: Effects of heparin coating of cardiopulmonary bypass circuits on in vitro oxygen free radical production during coronary bypass surgery. Artif Organs 1996, 20:1008-16.

34. Fukutomi M, Kobayashi S, Niwaya K, Hamada Y, Kitamura S: Changes in platelet, granulocyte, and complement activation during cardiopulmonary bypass using heparin-coated equipment. Artif Organs 1996, 20:767-76

35. Ranucci M, Cirri S, Conti D, Ditta A, Boncilli A, Frigiola A, Menicanti L: Beneficial effects of Duraflo II heparin-coated circuits on postperfusion lung dysfunction. Ann Thorac Surg 1996, 61:76-81.

36. Wildevuur $C R$, Jansen $P G$, Bezemer PD, Kuik DJ, Eijsman L, Bruins $P$, De Jong AP, Van Hardevelt FW, Biervliet JD, Hasenkam JM, Kure HH, Knudsen L, Bellaiche L, Ahlburg P, Loisance DY, Baufreton C, Le Besnerais P, Bajan G, Matta A, Van Dyck M, Renotte MT, Ponlot-Lois A, Baele P, McGovern EA, Ahlvin E: Clinical evaluation of Duraflo II heparin treated extracorporeal circulation circuits (2nd version). The European Working Group on heparin coated extracorporeal circulation circuits. Eur I Cardiothorac Surg 1997, 11:616-23.

37. Wan $S$, LeClerc JL, Antoine M, DeSmet JM, Yim AP, Vincent JL: Heparincoated circuits reduce myocardial injury in heart or heart-lung transplantation: a prospective, randomized study. Ann Thorac Surg 1999, 68:1230-5.

38. te Velthuis H, Baufreton C, Jansen PG, Thijs CM, Hack CE, Sturk A, Wildevuur CR, Loisance DY: Heparin coating of extracorporeal circuits inhibits contact activation during cardiac operations. J Thorac Cardiovasc Surg 1997, 114:117-22.

39. Gorman RC, Ziats N, Rao AK, Gikakis N, Sun L, Khan MM, Stenach N, Sapatnekar S, Chouhan V, Gorman JH III, Niewiarowski S, Colman RW, Anderson JM, Edmunds LH Jr: Surface-bound heparin fails to reduce thrombin formation during clinical cardiopulmonary bypass. $J$ Thorac Cardiovasc Surg 1996, 111:1-11.

40. Speekenbrink R, van Oeveren W, Wildevuur C: Pathophysiology of cardiopulmonary bypass, Minimally Invasive Cardiac Surgery. Totowa New Jersey Humana PressGolstein D, Oz M , 2 2004, 3-18.

41. Jegger D, Tevaearai HT, Horisberger J, Mueller XM, Boone Y, Pierrel $N$, Seigneul I, von Segesser LK: Augmented venous return for minimally invasive open heart surgery with selective caval cannulation. Eur J Cardiothorac Surg 1999, 16:312-6.

42. Nakanishi K, Shichijo T, Shinkawa Y, Takeuchi S, Nakai M, Kato G, Oba O: Usefulness of vacuum-assisted cardiopulmonary bypass circuit for pediatric open-heart surgery in reducing homologous blood transfusion. Eur J Cardiothorac Surg 2001, 20:233-8.

43. Rosengart TK, DeBois W, O'Hara M, Helm R, Gomez M, Lang SJ, Altorki N, Ko W, Hartman GS, Isom OW, Krieger KH: Retrograde autologous priming for cardiopulmonary bypass: a safe and effective means of decreasing hemodilution and transfusion requirements. $J$ Thorac Cardiovasc Surg 1998, 115:426-38.

44. Nollert G, Schwabenland I, Maktav D, Kur F, Christ F, Fraunberger P, Reichart B, Vicol C: Miniaturized cardiopulmonary bypass in coronary artery bypass surgery: marginal impact on inflammation and coagulation but loss of safety margins. Ann Thorac Surg 2005, 80:2326-32.

45. Bando K, Pillai R, Cameron DE, Brawn JD, Winkelstein JA, Hutchins GM Reitz BA, Baumgartner WA: Leukocyte depletion ameliorates free radicalmediated lung injury after cardiopulmonary bypass. J Thorac Cardiovasc Surg 1990, 99:873-7. 
46. Morioka K, Muraoka R, Chiba Y, Ihaya A, Kimura T, Noguti H, Uesaka T: Leukocyte and platelet depletion with a blood cell separator: effects on lung injury after cardiac surgery with cardiopulmonary bypass. J Thorac Cardiovasc Surg 1996, 111:45-54.

47. Sheppard SV: Mechanisms and technical aspects of leucocyte depletion, Leukocyte Depletion in Cardiac Surgery and Cardiology. Karger Matheis G, Moritz A, Scholz M 2002, 16-32.

48. Gu YJ, de Vries AJ, Vos P, Boonstra PW, van Oeveren W: Leukocyte depletion during cardiac operation: a new approach through the venous bypass circuit. Ann Thorac Surg 1999, 67:604-9.

49. Mihaljevic T, Tonz M, von Segesser LK, Pasic M, Grob P, Fehr J, Seifert B, Turina M: The influence of leukocyte filtration during cardiopulmonary bypass on postoperative lung function. A clinical study. J Thorac Cardiovasc Surg 1995, 109:1138-45.

50. Johnson D, Thomson D, Mycyk T, Burbridge B, Mayers I: Depletion of neutrophils by filter during aortocoronary bypass surgery transiently improves postoperative cardiorespiratory status. Chest 1995, 107:1253-9.

51. Hachida M, Hanayama N, Okamura T, Akasawa T, Maeda T, Bonkohara Y, Endo M, Hashimoto A, Koyanagi $\mathrm{H}$ : The role of leukocyte depletion in reducing injury to myocardium and lung during cardiopulmonary bypass. ASAIO J 1995, 41:M291-M294.

52. Sheppard S, Gipps R, Smith D: Does leukocyte depletion during cardiopulmonary bypass improve oxygenation indices in patients with mild lung dysfunction?. Br J Anesth 2004, 93:789-92.

53. Warren O, Alexiou C, Massey R, Leff D, Purkayastha S, Kinross J, Darzi A, Athanasiou $\mathrm{T}$ : The effects of various leukocyte filtration strategies in cardiac surgery. Eur J Cardiothorac Surg 2007, 31:665-76.

54. Huang H, Yao T, Wang W, Zhu D, Zhang W, Chen H, Fu W: Continuous ultrafiltration attenuates the pulmonary injury that follows open heart surgery with cardiopulmonary bypass. Ann Thorac Surg 2003, 76:136-40.

55. Keenan HT, Thiagarajan R, Stephens KE, Williams G, Ramamoorthy C, Lupinetti FM: Pulmonary function after modified venovenous ultrafiltration in infants: a prospective, randomized trial. $J$ Thorac Cardiovasc Surg 2000, 119:501-5.

56. Pearl JM, Manning PB, MCNamara JL, Saucier MM, Thomas DW: Effect of modified ultrafiltration on plasma thromboxane B2, leukotriene B4, and endothelin- 1 in infants undergoing cardiopulmonary bypass. Ann Thorac Surg 1999, 68:1369-75.

57. Mahmoud AB, Burhani MS, Hannef AA, Jamjoom AA, Al Githmi IS, Baslaim GM: Effect of modified ultrafiltration on pulmonary function after cardiopulmonary bypass. Chest 2005, 128:3447-53.

58. Nagashima M, Shin'oka T, Nollert G, Shum-Tim D, Rader CM, Mayer JE Jr: High-volume continuous hemofiltration during cardiopulmonary bypass attenuates pulmonary dysfunction in neonatal lambs after deep hypothermic circulatory arrest. Circulation 1998, 98:|1378-||384.

59. DeFoe GR, Ross CS, Olmstead EM, Surgenor SD, Fillinger MP, Groom RC, Forest RJ, Pieroni JW, Warren CS, Bogosian ME, Krumholz CF, Clark C, Clough RA, Weldner PW, Lahey SJ, Leavitt BJ, Marrin CA, Charlesworth DC, Marshall P, O'Connor GT: Lowest hematocrit on bypass and adverse outcomes associated with coronary artery bypass grafting. Ann Thorac Surg Northern New England Cardiovascular Disease Study Group 2001, 71:769-76.

60. Jansen $P$, te Velthuis $H$, Wildevuur W: Cardiopulmonary bypass with modified fluid gelatine and heparin-coated circuits. Br J Anesth 1996, 6:13-9.

61. Takai H, Eishi K, Yamachika S, Hazama S, Nishi K, Ariyoshi T, Nakaji S, Matsumaru l: The efficacy of low prime volume completely closed cardiopulmonary bypass in coronary artery revascularization. Ann Thorac Cardiovasc Surg 2004, 10:178-82.

62. Philippou H, Adami A, Davidson SJ, Pepper JR, Burman JF, Lane DA: Tissue factor is rapidly elevated in plasma collected from the pericardial cavity during cardiopulmonary bypass. Thromb Haemost 2000, 84:124-8.

63. de Haan J, Boonstra PW, Monnink SH, Ebels T, van Oeveren W: Retransfusion of suctioned blood during cardiopulmonary bypass impairs hemostasis. Ann Thorac Surg 1995, 59:901-7.

64. Schoenberger J, van Overen W, Bredee J: Systemic blood activation during and after auto-transplantation. Ann Thorac Surg 1994, 57:1256-62.

65. Boonstra PW, van Imhoff GW, Eysman L, Kootstra GJ, Heide van der JN, Karliczek GF, Wildevuur CR: Reduced platelet activation and improved hemostasis after controlled cardiotomy suction during clinical membrane oxygenator perfusions. J Thorac Cardiovasc Surg 1985, 89:9006.

66. Tatar H, Cicek S, Demirkilic U, Ozal E, Suer H, Ozturk O, Isiklar H: Topical use of aprotinin in open heart operations. Ann Thorac Surg 1993, 55:659-61.

67. Tabuchi N, de Haan J, Boonstra PW, van Oeveren W: Activation of fibrinolysis in the pericardial cavity during cardiopulmonary bypass. $J$ Thorac Cardiovasc Surg 1993, 106:828-33.

68. Lodge AJ, Chai PJ, Daggett CW, Ungerleider RM, Jaggers J: Methylprednisolone reduces the inflammatory response to cardiopulmonary bypass in neonatal piglets: timing of dose is important. J Thorac Cardiovasc Surg 1999, 117:515-22.

69. Wan $S$, LeClerc $J$, Vincent $J$ : Inflammatory response to cardiopulmonary bypass: mechanisms involved and possible therapeutic strategies. Chest 1997, 112:676-92.

70. Jansen NJ, van Oeveren W, van Vliet M, Stoutenbeek CP, Eysman L, Wildevuur CR: The role of different types of corticosteroids on the inflammatory mediators in cardiopulmonary bypass. Eur J Cardiothorac Surg 1991, 5:211-7.

71. Hill GE, Alonso A, Spurzem JR, Stammers AH, Robbins RA: Aprotinin and methylprednisolone equally blunt cardiopulmonary bypass-induced inflammation in humans. J Thorac Cardiovasc Surg 1995, 110:1658-62.

72. Tassani P, Richter JA, Barankay A, Braun SL, Haehnel C, Spaeth P, Schad H, Meisner $\mathrm{H}$ : Does high-dose methylprednisolone in aprotinin-treated patients attenuate the systemic inflammatory response during coronary artery bypass grafting procedures?. J Cardiothorac Vasc Anesth 1999, 13:165-72.

73. Chaney MA, Nikolov MP, Blakeman B, Bakhos M, Slogoff S: Pulmonary effects of methylprednisolone in patients undergoing coronary artery bypass grafting and early tracheal extubation. Anesth Analg 1998, 87:2733.

74. Chaney MA, Durazo-Arvizu RA, Nikolov MP, Blakeman BP, Bakhos M: Methylprednisolone does not benefit patients undergoing coronary artery bypass grafting and early tracheal extubation. J Thorac Cardiovasc Surg 2001, 121:561-9.

75. Hill GE, Pohorecki R, Alonso A, Rennard SI, Robbins RA: Aprotinin reduces interleukin-8 production and lung neutrophil accumulation after cardiopulmonary bypass. Anesth Analg 1996, 83:696-700.

76. Seghaye MC, Duchateau J, Grabitz RG, Jablonka K, Wenzl T, Marcus C, Messmer BJ, von Bernuth G: Influence of low-dose aprotinin on the inflammatory reaction due to cardiopulmonary bypass in children. Ann Thorac Surg 1996, 61:1205-11.

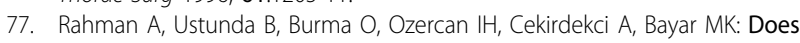
aprotinin reduce lung reperfusion damage after cardiopulmonary bypass?. Eur J Cardiothorac Surg 2000, 18:583-8.

78. Prendergast TW, Furukawa S, Beyer AJ III, Eisen HJ, Mc Clurken JB, Jeevanandam V: Defining the role of aprotinin in heart transplantation. Ann Thorac Surg 1996, 62:670-4

79. Upchurch GR, Valeri CR, Khuri SF, Rohrer MJ, Welch GN, MacGregor H, Ragno G, Francis S, Rodino $\sqcup$, Michelson AD, Loscalzo J: Effect of heparin on fibrinolytic activity and platelet function in vivo. Am J Physiol 1996, 271:H528-H534.

80. John LC, Rees GM, Kovacs IB: Inhibition of platelet function by heparin. An etiologic factor in postbypass hemorrhage. J Thorac Cardiovasc Surg 1993, 105:816-22.

81. Videm V: Heparin in clinical doses 'primes' granulocytes to subsequent activation as measured by myeloperoxidase release. Scand I Immunol 1996, 43:385-90.

82. Shastri KA, Logue GL, Stern MP, Rehman S, Raza S: Complement activation by heparin-protamine complexes during cardiopulmonary bypass: effect of C4A null allele. J Thorac Cardiovasc Surg 1997, 114:482-8.

83. Dehmer GJ, Fisher M, Tate DA, Teo S, Bonnem EM: Reversal of heparin anticoagulation by recombinant platelet factor 4 in humans. Circulation 1995, 91:2188-94.

84. Riess FC, Potzsch B, Behr I, Jager K, Rossing R, Bleese N, Schaper W, MullerBerghaus $G$ : Recombinant hirudin as an anticoagulant during cardiac operations: experiments in a pig model. Eur J Cardiothorac Surg 1997, 11:739-45.

85. Muller H, Hugel W, Reifschneider HJ, Horpacsy G, Hannekum A, Dalichau H: Lysosomal enzyme activity influenced by various types of respiration during extracorporeal circulation. Thorac Cardiovasc Surg 1989, 37:65-71. 
86. Magnusson L, Zemgulis V, Tenling A, Wernlund J, Tyden $H$, Thelin S, Hedenstierna G: Use of a vital capacity maneuver to prevent atelectasis after cardiopulmonary bypass: an experimental study. Anesthesiology 1998, 88:134-42.

87. Ishikawa S, Ohtaki A, Takahashi T, Sakata K, Koyano T, Kano M, Ohki S, Kawashima O, Hamada Y, Morishita Y: PEEP therapy for patients with pleurotomy during coronary artery bypass grafting. J Card Surg 2000, 15:175-8.

88. Berry CB, Butler PJ, Myles PS: Lung management during cardiopulmonary bypass: is continuous positive airways pressure beneficial?. Br J Anaesth 1993, 71:864-8.

89. Stanley TH, Liu WS, Gentry S: Effects of ventilatory techniques during cardiopulmonary bypass on post-bypass and postoperative pulmonary compliance and shunt. Anesthesiology 1977, 46:391-5.

90. Friedman M, Sellke FW, Wang SY, Weintraub RM, Johnson RG: Parameters of pulmonary injury after total or partial cardiopulmonary bypass. Circulation 1994, 90:11262-II268.

91. Serraf A, Robotin M, Bonnet N, Detruit H, Baudet B, Mazmanian MG, Herve P, Planche C: Alteration of the neonatal pulmonary physiology after total cardiopulmonary bypass. J Thorac Cardiovasc Surg 1997, 114:1061-9.

92. John L, Ervine I: A study assessing the potential benefit of continued ventilation during cardiopulmonary bypass. Interactive Cardiovascular and Thoracic Surgery 2008, 7:14-17.

93. Keavey PM, Hasan A, Au J, Dark JH: The use of 99Tcm-DTPA aerosol and caesium iodide mini-scintillation detectors in the assessment of lung injury during cardiopulmonary bypass surgery. Nucl Med Commun 1997, 18:38-43.

94. Davies MG, Hagen PO: Systemic inflammatory response syndrome. $\mathrm{Br} J$ Surg 1997, 84:920-35.

95. Laffey J, Boylan J, Cheng D: The Systemic Inflammatory Response to Cardiac Surgery. Anesthesiology 2002, 97:215-252.

96. Menasche P, Piwnica A: Free radicals and myocardial protection: a surgical viewpoint. Ann Thorac Surg 1989, 47:939-45.

97. Seccombe JF, Pearson PJ, Schaff HV: Oxygen radical-mediated vascular injury selectively inhibits receptor-dependent release of nitric oxide from canine coronary arteries. J Thorac Cardiovasc Surg 1994, 107:505-9.

98. Haniuda M, Dresler CM, Mizuta T, Cooper JD, Patterson GA: Free radicalmediated vascular injury in lungs preserved at moderate hypothermia. Ann Thorac Surg 1995, 60:1376-81.

99. Lichtenstein SV, Ashe KA, el Dalati H, Cusimano RJ, Panos A, Slutsky AS: Warm heart surgery. J Thorac CardiovasC Surg 1991, 101:269-74.

100. Pyles LA, Fortney JE, Kudlak JJ, Gustafson RA, Einzig S: Plasma antioxidant depletion after cardiopulmonary bypass in operations for congenital heart disease. J Thorac Cardiovasc Surg 1995, 110:165-71.

101. Seccombe JF, Schaff HV: Coronary artery endothelial function after myocardial ischemia and reperfusion. Ann Thorac Surg 1995, 60:778-88.

102. Kaneda T, Ku K, Inoue T, Onoe M, Oku H: Postischemic reperfusion injury can be attenuated by oxygen tension control. Jpn Circ J 2001, 65:213-8.

103. Diegeler A, Doll N, Rauch T, Haberer D, Walther T, Falk V, Gummert J, Autschbach R, Mohr FW: Humoral immune response during coronary artery bypass grafting: A comparison of limited approach, "off-pump" technique, and conventional cardiopulmonary bypass. Circulation 2000, 102: $11195-100$.

104. Wan S, Izzat MB, Lee TW, Wan IY, Tang NL, Yim AP: Avoiding cardiopulmonary bypass in multivessel CABG reduces cytokine response and myocardial injury. Ann Thorac Surg 1999, 68:52-6.

105. Massoudy P, Zahler S, Tassani P, Becker BF, Richter JA, Pfauder M, Lange R, Meisner $\mathrm{H}$ : Reduction of pro-inflammatory cytokine levels and cellular adhesion in CABG procedures with separated pulmonary and systemic extracorporeal circulation without an oxygenator. Eur J Cardiothorac Surg 2000, 17:729-36

106. Massoudy P, Piotrowski JA, Wal van de HC, Giebler R, Marggraf G, Peters J, Jakob HG: Perfusing and ventilating the patient's lungs during bypass ameliorates the increase in extravascular thermal volume after coronary bypass grafting. Ann Thorac Surg 2003, 76:516-21.

107. Suzuki T, Fukuda T, Ito T, Inoue Y, Cho Y, Kashima I: Continuous pulmonary perfusion during cardiopulmonary bypass prevents lung injury in infants. Ann Thorac Surg 2000, 69:602-6.
108. Mendler N, Heimisch W, Schad H: Pulmonary function after biventricular bypass for autologous lung oxygenation. Eur J Cardiothorac Surg 2000, 17:325-30

109. Dobell AR, Bailey JS: Charles Drew and the origins of deep hypothermic circulatoryarrest. Ann Thorac Surg 1997, 63:1193-9.

110. Richter JA, Meisner H, Tassani P, Barankay A, Dietrich W, Braun SL: DrewAnderson technique attenuates systemic inflammatory response syndrome and improves respiratory function after coronary artery bypass grafting. Ann Thorac Surg 2000, 69:77-83.

doi:10.1186/1749-8090-5-1

Cite this article as: Apostolakis et al.: Strategies to prevent intraoperative lung injury during cardiopulmonary bypass. Journal of Cardiothoracic Surgery 2010 5:1.
Publish with Biomed Central and every scientist can read your work free of charge

"BioMed Central will be the most significant development for disseminating the results of biomedical research in our lifetime. "

Sir Paul Nurse, Cancer Research UK

Your research papers will be:

- available free of charge to the entire biomedical community

- peer reviewed and published immediately upon acceptance

- cited in PubMed and archived on PubMed Central

- yours - you keep the copyright 